\title{
Identification of Xanthomonas species associated with bacterial leaf spot of tomato, capsicum and chilli crops in eastern Australia
}

\author{
R. Roach (i) • R. Mann • C. G. Gambley • R. G. Shivas • \\ B. Rodoni
}

Accepted: 14 July 2017 / Published online: 25 July 2017

(C) The Author(s) 2017. This article is an open access publication

\begin{abstract}
Several species of Xanthomonas cause bacterial leaf spot, a disease that affects solanaceous crops worldwide. The diversity of 64 Australian isolates of Xanthomonas spp. associated with bacterial leaf spot in tomato, capsicum and chilli crops in eastern Australia was determined using multi-locus sequence analysis of $a t p D, d n a K$, efp and $g y r B$ genes, species-specific PCR assays and biochemical analyses. At least five species of Xanthomonas associated with bacterial leaf spot were identified in Australian tomato, capsicum and chilli crops and their pathogenicity assessed. Phylogenetic and biochemical analyses identified $X$. euvesicatoria,
\end{abstract}

GenBank accession numbers: KY658725-KY658788, KY658789-KY658852, KY658853-KY658916, KY658917KY658975, KY364014-KY364018.

Electronic supplementary material The online version of this article (doi:10.1007/s10658-017-1303-9) contains supplementary material, which is available to authorized users.

R. Roach · R. G. Shivas

Department of Agriculture and Fisheries, Ecosciences Precinct, Brisbane, QLD, Australia

R. Roach $(\bowtie) \cdot$ R. Mann $\cdot$ B. Rodoni

Department of Environment and Primary Industries, La Trobe University, Melbourne, VIC, Australia

e-mail: roach.r@students.latrobe.edu.au

C. G. Gambley

Department of Agriculture and Fisheries, Applethorpe Research Facility, Stanthorpe, QLD, Australia
$X$. perforans and $X$. vesicatoria as the most frequently recovered pathogenic species. Non-pathogenic and weakly pathogenic species were also identified. The suitability of the identification methods used and the implications of the detection of these species will be discussed.

Keywords amylolytic $\cdot$ pectolytic $\cdot$ Solanaceae $\cdot$ disease management

\section{Introduction}

Bacterial leaf spot (BLS) is a disease of solanaceous crops that occurs worldwide, especially in warm and humid climates (Jones et al. 2014). Several species of Xanthomonas are reported to cause BLS of tomato (Solanum lycopersicum), capsicum and chilli (Capsicum annuum) (Potnis et al. 2015). The symptoms of BLS are small, brown, angular, water-soaked lesions on leaves, stems and fruit, and result in defoliation and direct fruit damage. Severe infection may result in extensive damage to crops with significant yield losses (Pernezny et al. 2003). Species reported to cause BLS all produce similar symptoms on their hosts, making precise diagnosis difficult from visual symptoms alone. The impact of pathological convergence and importance of phylogenetic testing in the case of BLS are further highlighted by Hajri et al. (2009). The causal bacteria are spread by wind and water, and may survive in crop residues, weeds and volunteer plants (Jones et al. 1986). A link between field disease and seed contamination has 
been apparent for almost a century (Higgins 1922; Shekhawat and Chakravarti 1979). Control of BLS is achieved primarily through the use of resistant lines, antibiotic application and copper sprays. Reliance on a limited range of chemicals has seen copper and antibiotic resistance develop rapidly in Xanthomonas populations (Griffin et al. 2017; Martin et al. 2004; Minsavage et al. 1990).

Four species of Xanthomonas reported to cause BLS are X. euvesicatoria (Jones et al. 2006), X. gardneri (ex Sutic 1957; Jones et al. 2006), $X$. perforans (Jones et al. 2006), and X. vesicatoria (ex Doidge 1920; Vauterin et al. 1995). These species were once classified in the $X$. campestris pv. vesicatoria species complex (Young et al. 1978) and the most recent Australian report of BLS refers to $X$. campestris pv. vesicatoria (Martin et al. 2004). A recent study by Constantin et al. (2016) proposed merging $X$. perforans and $X$. euvesicatoria as they and others have noted synonymy in these species (Potnis et al. 2015). The identification and detection of these species is typically achieved through the use of various molecular techniques (eg. PCR, MLSA, NGS) as the taxonomy has moved beyond the point where traditional biochemical techniques effectively distinguish these groups. Xanthomonas spp. that cause BLS in tomato and capsicum crops are reported from several countries (EPPO 2013; Timilsina et al. 2015). Strains of Xanthomonas arboricola (Vauterin et al. 1995) have been shown to cause BLS on capsicum in Korea and has also been associated with disease outbreaks on tomato in Tanzania (Mbega et al. 2012; Myung et al. 2010). A Xanthomonas sp. reported on tomato in Tanzania was genetically distinct from the four commonly reported species based on a phylogeny of fyuA sequence (Mbega et al. 2012). Xanthomonas campestris pv. raphani has also been noted to cause BLS on tomato (Punina et al. 2009). Non-pathogenic species of Xanthomonas have also been recorded, potentially complicating the detection of pathogens (Vauterin et al. 1996). The distribution and prevalence of BLS-causing Xanthomonas species in Australia is relatively unknown (EPPO 2013).

BLS was first reported in Australia in 1944 (Anonymous 1944) and continues to impact crop production. The 2014/15 production value of Australian capsicum and chilli industries were valued at $\$ 144.7 \mathrm{M}$ and $\$ 9.6 \mathrm{M}$ respectively. The production value of Australian tomato was $\$ 548 \mathrm{M}$, with the majority of all three crops grown in Queensland (HIA 2016). Though outbreaks of BLS occur in most commercial growing regions in Australia, little has been done to investigate the genetic diversity and distribution of the causal Xanthomonas species. The development of effective management strategies, primarily the selection of resistant plant material, relies upon the accurate identification of pathogens and an understanding of their diversity and pathogenicity. This study describes the identification and diversity of pathogenic and nonpathogenic Xanthomonas spp. associated with BLS in Australia based on biochemical and molecular analysis.

\section{Materials and methods}

Specimen collection

Capsicum, chilli and tomato crops were surveyed for BLS symptoms during the 2015 growing season in Queensland (Qld) and New South Wales (NSW). Symptomatic tissue was collected from sites around eastern Australia (Fig. 1). Lesions were examined for bacterial streaming and initial isolations were made on Nutrient Agar (NA, Astral Scientific Pty Ltd) (Schaad 2001). Xanthomonas-like bacteria were single colony purified and stored at $-80{ }^{\circ} \mathrm{C}$ in $2 \mathrm{ml}$ Microbank $^{\mathrm{TM}}$ vials (Pro-Lab Diagnostics Inc.) and deposited in the culture collection of the Queensland Plant Pathology Herbarium (BRIP). Type strains for X. euvesicatoria (NCPPB 2968), X. gardneri (NCPPB 881), $X$. perforans (NCPPB 4321) and $X$. vesicatoria (NCPPB 422) were imported under permit from the National Collection of Plant Pathogenic Bacteria (NCPPB). A further seven unidentified isolates of Xanthomonas from solanaceous hosts were sourced from the BRIP culture collection. All of the bacterial isolates examined in this study are shown in Table 1, with additional reference sequence from GenBank shown in Table 3 (supplementary data).

Biochemical analysis and pathogenicity

Biochemical tests were conducted on 48 h-old cultures taken from storage and grown on NA at room temperature. Oxidase, catalase and potassium hydroxide $(\mathrm{KOH})$ tests and media preparation were done as described by Schaad (2001). Cultures were streaked on to 
Fig. 1 Xanthomonas species distribution across the surveyed areas of eastern Australia. Colours represent species determined by phylogenetic clades generated using multilocus sequence analysis (Fig. 3)

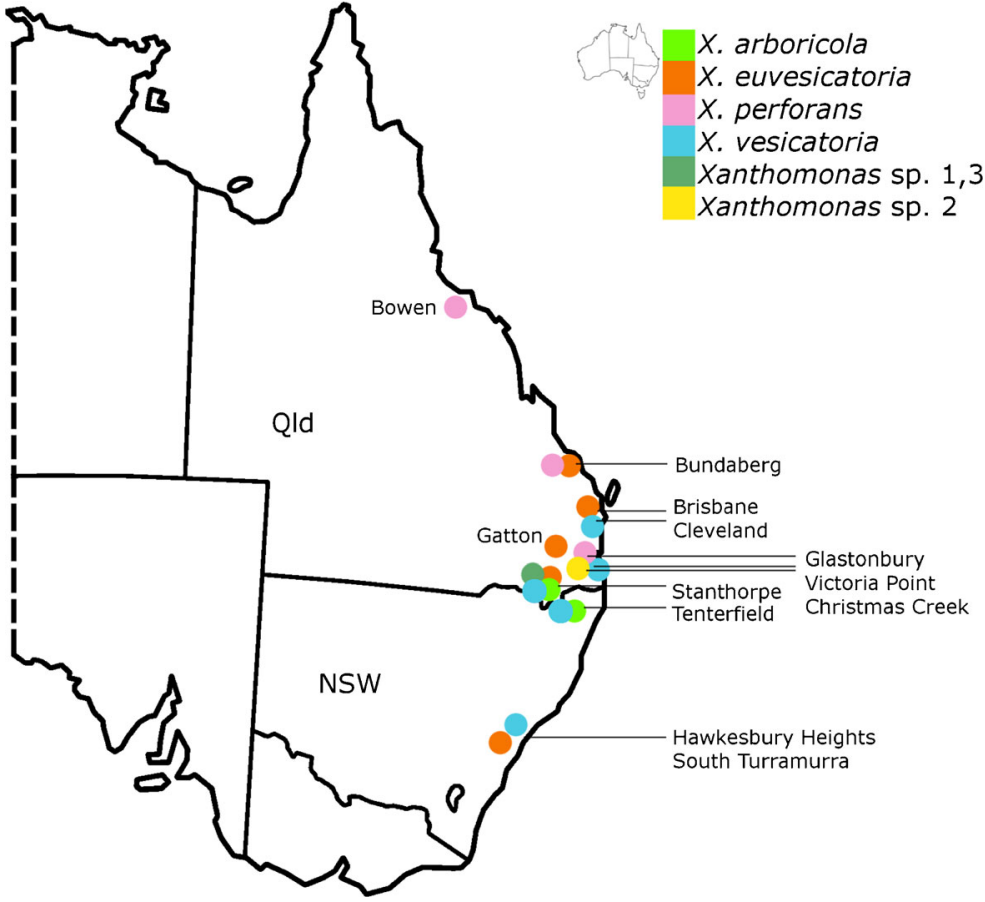

starch, pectin and yeast extract-dextrose-calcium carbonate (YDC) media, and the morphology recorded after 48-72 h (Schaad 2001). Biochemical data was displayed as a cluster analysis (Fig. 2) by assigning each result a binary value ( $1=$ positive, $0=$ negative $)$. The cluster and dendrogram were created in $\mathrm{R}$ ( $\mathrm{R}$ core team 2016).

To confirm pathogenicity on the host of isolation, bacteria were grown on nutrient agar overnight (Schaad 2001) at room temperature and then suspended in sterile distilled water. The concentration of the inoculum solution was measured using a BioDrop DUO (BioDrop) spectrophotometer and adjusted to $\mathrm{OD}_{600}=0.2\left(1 \times 10^{8} \mathrm{cfu} / \mathrm{ml}\right)$ with sterile distilled water. Leaf panels of Capsicum annuum var. Jupiter or Solanum lycopersicum var. Grosse Lisse at the 2-4 true leaf stage were infiltrated with $300 \mu \mathrm{l}$ of inoculum using a $1 \mathrm{ml}$ syringe. Sterile distilled water was used as a control. Water-soaked lesions were deemed a susceptible reaction and tan papery lesions a hypersensitive response. Isolates representing each phylogenetic clade (62409-62412, 62414-62418, 62432, 39016, 38864, 62555, 63565, 62428 ) were then prepared as above and spray inoculated to confirm symptomatic pathogenicity. Isolates from non-crop hosts BRIP 39016 and 38864 were inoculated on tomato by infiltration and spray as described above.

Gene amplification and sequencing

DNA template was prepared by suspending a single pure colony in $100 \mu \mathrm{l}$ milliQ water, incubated at $95^{\circ} \mathrm{C}$ for $7 \mathrm{~min}$ and then used for species-specific and MLSA associated PCRs. PCR protocols developed to differentiate $X$. euvesicatoria, $X$. gardneri, $X$. perforans and $X$. vesicatoria were used for all isolates including type strains which were used as positive controls (Koenraadt et al. 2009). PCRs were performed as described in Koenraadt et al. (2009) using $2.5 \mathrm{U}$ of MangoTaq ${ }^{\mathrm{TM}}$ (Bioline) and $1 \mu \mathrm{l}$ of template. Primers and their annealing temperatures are listed in Table 2.

MLSA-PCR primers targeting the chaperone protein dnaK (dnaK), elongation factor P (efp), ATP synthase subunit beta $(a t p D)$ and DNA gyrase subunit B $(g y r B)$ genes (Table 2) were used as described (Boudon et al. 2005; Ah-You et al. 2009; Ngoc et al. 2010; Hamza et al. 2012). Annealing temperatures were optimised for the MLSA primers targeting all four genes. PCR products were purified and sequenced by Macrogen Inc. (South Korea) in both directions using an Applied Biosystems 3730xl DNA Analyser. 
Table 1 Collection data, GenBank accession numbers and species-specific PCR results for isolates collected and type isolates used in this study

\begin{tabular}{|c|c|c|c|c|c|}
\hline Organism $^{c}$ & Accession no. & Location & Host & Collection year & Species specific PCR result ${ }^{b}$ \\
\hline$X$. arboricola & BRIP 62410 & Stanthorpe & Tomato & 2015 & 0 \\
\hline$X$. arboricola & BRIP 62412 & Stanthorpe & Tomato & 2015 & 0 \\
\hline X. arboricola & BRIP 62414 & Stanthorpe & Tomato & 2015 & 0 \\
\hline X. arboricola & BRIP 62416 & Stanthorpe & Tomato & 2015 & 0 \\
\hline$X$. arboricola & BRIP 62432 & Tenterfield & Tomato & 2015 & 0 \\
\hline X. euvesicatoria & NCPPB $2968^{\mathrm{T}}$ & USA & Chilli (Capsicum frutescens) & 1977 & $\mathrm{Xe}$ \\
\hline X. euvesicatoria & BRIP 38855 & Bundaberg & Capsicum & 1981 & $\mathrm{Xe}$ \\
\hline X. euvesicatoria & BRIP 63464 & Bundaberg & Capsicum & 2015 & $\mathrm{Xe}$ \\
\hline X. euvesicatoria & BRIP 62439 & Bundaberg & Chilli $^{a}$ & 2015 & $\mathrm{Xe}$ \\
\hline X. euvesicatoria & BRIP 62440 & Bundaberg & Chilli & 2015 & $\mathrm{Xe}$ \\
\hline X. euvesicatoria & BRIP 62441 & Bundaberg & Chilli & 2015 & $\mathrm{Xe}$ \\
\hline X. euvesicatoria & BRIP 62442 & Bundaberg & Chilli & 2015 & $\mathrm{Xe}$ \\
\hline X. euvesicatoria & BRIP 62443 & Bundaberg & Chilli & 2015 & $\mathrm{Xe}$ \\
\hline X. euvesicatoria & BRIP 62555 & Bundaberg & Chilli & 2015 & $\mathrm{Xe}$ \\
\hline X. euvesicatoria & BRIP 62656 & Bundaberg & Chilli & 2015 & $\mathrm{Xe}$ \\
\hline X. euvesicatoria & BRIP 62757 & Bundaberg & Chilli & 2015 & $\mathrm{Xe}$ \\
\hline X. euvesicatoria & BRIP 62858 & Bundaberg & Chilli & 2015 & $\mathrm{Xe}$ \\
\hline X. euvesicatoria & BRIP 62959 & Bundaberg & Chilli & 2015 & $\mathrm{Xe}$ \\
\hline X. euvesicatoria & BRIP 38997 & Bundaberg & Chilli & 1986 & $\mathrm{Xe}$ \\
\hline X. euvesicatoria & BRIP 62454 & Bundaberg & Chilli (C. chinense) & 2015 & $\mathrm{Xe}$ \\
\hline X. euvesicatoria & BRIP 62390 & Gatton & Capsicum & 2014 & $\mathrm{Xe}$ \\
\hline X. euvesicatoria & BRIP 62391 & Gatton & Capsicum & 2014 & $\mathrm{Xe}$ \\
\hline X. euvesicatoria & BRIP 62392 & Gatton & Capsicum & 2014 & $\mathrm{Xe}$ \\
\hline X. euvesicatoria & BRIP 62393 & Gatton & Capsicum & 2014 & $\mathrm{Xe}$ \\
\hline$X$. euvesicatoria & BRIP 62394 & Gatton & Capsicum & 2014 & $\mathrm{Xe}$ \\
\hline X. euvesicatoria & BRIP 62395 & Gatton & Capsicum & 2014 & $\mathrm{Xe}$ \\
\hline$X$. euvesicatoria & BRIP 62396 & Gatton & Chilli & 2014 & $\mathrm{Xe}$ \\
\hline X. euvesicatoria & BRIP 62399 & Gatton & Chilli & 2014 & $\mathrm{Xe}$ \\
\hline X. euvesicatoria & BRIP 62400 & Gatton & Chilli & 2014 & $\mathrm{Xe}$ \\
\hline X. euvesicatoria & BRIP 62401 & Gatton & Chilli & 2014 & $\mathrm{Xe}$ \\
\hline X. euvesicatoria & BRIP 62402 & Gatton & Chilli & 2014 & $\mathrm{Xe}$ \\
\hline X. euvesicatoria & BRIP 62403 & Gatton & Chilli & 2014 & $\mathrm{Xe}$ \\
\hline X. euvesicatoria & BRIP 62434 & Gatton & Chilli & 2015 & $\mathrm{Xe}$ \\
\hline X. euvesicatoria & BRIP 62435 & Gatton & Chilli & 2015 & $\mathrm{Xe}$ \\
\hline X. euvesicatoria & BRIP 39000 & Glastonbury & Chilli & 1986 & $\mathrm{Xe}$ \\
\hline X. euvesicatoria & BRIP 62438 & Hawkesbury Heights & Capsicum & 2015 & $\mathrm{Xe}$ \\
\hline X. euvesicatoria & BRIP 62425 & Stanthorpe & Capsicum & 2015 & $\mathrm{Xe}$ \\
\hline X. gardneri & NCPPB $881^{\mathrm{T}}$ & Yugoslavia & Tomato & 1961 & $\mathrm{Xg}$ \\
\hline$X$. perforans & $\mathrm{NCPPB} 4321^{\mathrm{T}}$ & USA & Tomato & 2004 & $\mathrm{Xp}$ \\
\hline$X$. perforans & BRIP 62383 & Bowen & Tomato & 2012 & 0 \\
\hline$X$. perforans & BRIP 62384 & Bowen & Tomato & 2012 & 0 \\
\hline$X$. perforans & BRIP 62385 & Bowen & Tomato & 2012 & 0 \\
\hline$X$. perforans & BRIP 62387 & Bowen & Tomato & 2012 & 0 \\
\hline
\end{tabular}


Table 1 (continued)

\begin{tabular}{|c|c|c|c|c|c|}
\hline Organism $^{\mathrm{c}}$ & Accession no. & Location & Host & Collection year & Species specific PCR result ${ }^{b}$ \\
\hline$X$. perforans & BRIP 62398 & Bowen & Tomato & 2014 & 0 \\
\hline$X$. perforans & BRIP 62404 & Bowen & Tomato & 2014 & 0 \\
\hline$X$. perforans & BRIP 62397 & Brisbane & Tomato & 2014 & 0 \\
\hline$X$. perforans & BRIP 62386 & Bundaberg & Tomato & 2012 & 0 \\
\hline$X$. perforans & BRIP 62405 & Bundaberg & Tomato & 2014 & 0 \\
\hline$X$. perforans & BRIP 63262 & Bundaberg & Tomato & 2015 & 0 \\
\hline$X$. perforans & BRIP 63565 & Bundaberg & Tomato & 2015 & 0 \\
\hline$X$. perforans & BRIP 63666 & Bundaberg & Tomato & 2015 & 0 \\
\hline$X$. perforans & BRIP 62389 & South Turramurra & Tomato & 2013 & 0 \\
\hline$X$. vesicatoria & NCPPB $422^{\mathrm{T}}$ & $\mathrm{NZ}$ & Tomato & 1957 & $\mathrm{Xv}$ \\
\hline$X$. vesicatoria & BRIP 38864 & Bowen & S. peruvianum & 1982 & $\mathrm{Xv}$ \\
\hline$X$. vesicatoria & BRIP 39109 & Cleveland & Tomato & 1976 & $\mathrm{Xv}$ \\
\hline$X$. vesicatoria & BRIP 62388 & South Turramurra & Tomato & 2012 & $\mathrm{Xv}$ \\
\hline$X$. vesicatoria & BRIP 62423 & Stanthorpe & Tomato & 2015 & $\mathrm{Xv}$ \\
\hline$X$. vesicatoria & BRIP 62429 & Tenterfield & Tomato & 2015 & $\mathrm{Xv}$ \\
\hline$X$. vesicatoria & BRIP 62430 & Tenterfield & Tomato & 2015 & $\mathrm{Xv}$ \\
\hline$X$. vesicatoria & BRIP 62428 & Tenterfield & Tomato & 2015 & $\mathrm{Xv}$ \\
\hline$X$. vesicatoria & BRIP 38861 & Victoria Point & Tomato & 1981 & $\mathrm{Xv}$ \\
\hline$X$. vesicatoria & BRIP 62413 & Stanthorpe & Tomato & 2015 & 0 \\
\hline Xanthomonas sp. & BRIP 39016 & Christmas Creek & N. physalodes & 1973 & 0 \\
\hline Xanthomonas sp. & BRIP 62409 & Stanthorpe & Tomato & 2015 & 0 \\
\hline Xanthomonas sp. & BRIP 62411 & Stanthorpe & Tomato & 2015 & 0 \\
\hline Xanthomonas sp. & BRIP 62415 & Stanthorpe & Tomato & 2015 & 0 \\
\hline Xanthomonas sp. & BRIP 62417 & Stanthorpe & Tomato & 2015 & 0 \\
\hline Xanthomonas sp. & BRIP 62418 & Stanthorpe & Tomato & 2015 & 0 \\
\hline
\end{tabular}

\footnotetext{
${ }^{\mathrm{T}}$ indicates type strains from the National Collection of Plant Pathogenic Bacteria (NCPPB), Fera, UK

${ }^{a}$ C. annuum variety unless otherwise stated

${ }^{\mathrm{b}}$ positive reaction in the species-specific PCR for X. euvesicatoria (Xe), X. gardneri (Xg), X. perforans (Xp) or X. vesicatoria (Xv), negative in all four PCRs indicated by 0

${ }^{\mathrm{c}}$ species designation based on MLSA (Fig. 3)
}

Sequence analysis

Geneious (v. 9.1.2) was used to process and analyse sequence data (Kearse et al. 2012). Sequence reads were manually trimmed by quality scores and compared to the non-redundant database in GenBank using the BLASTn algorithm (Madden 2003). Sequences generated in this study were deposited in GenBank (Table 4 supplementary data). Trimmed sequences were aligned with reference sequences of Xanthomonas spp. atpD, dnaK, efp, and gyrB genes (supplementary Table 3) available on GenBank (Benson et al. 2005) using clustalW (Larkin et al. 2007). Sequences from Hamza et al. (2010, 2012) and the top BLASTn hit for each gene of isolates in unresolved clades were included in the MLSA analysis. The outgroup taxa were Stenotrophomonas maltophilia, X. albilineans and X. campestris pv. raphani. Other sequences of $X$. arboricola from capsicum and tomato were not included in this analysis due to lack of available sequence data. Bayesian inference (BI) was used to construct a phylogeny of concatenated gene sequences of $a t p D$, dnaK, efp, and gyrB. Phylogenetic trees were produced for individual genes and concatenated gene sequences using MrBayes ver. 3.2.6 (Huelsenbeck and Ronquist 2001) for Bayesian estimation with a GTR gamma model chosen with jmodeltest2 (Darriba et al. 2012; Guindon and Gascuel 2003) and $1,100,000$ chain with a burn-in of 100,000 sampled 


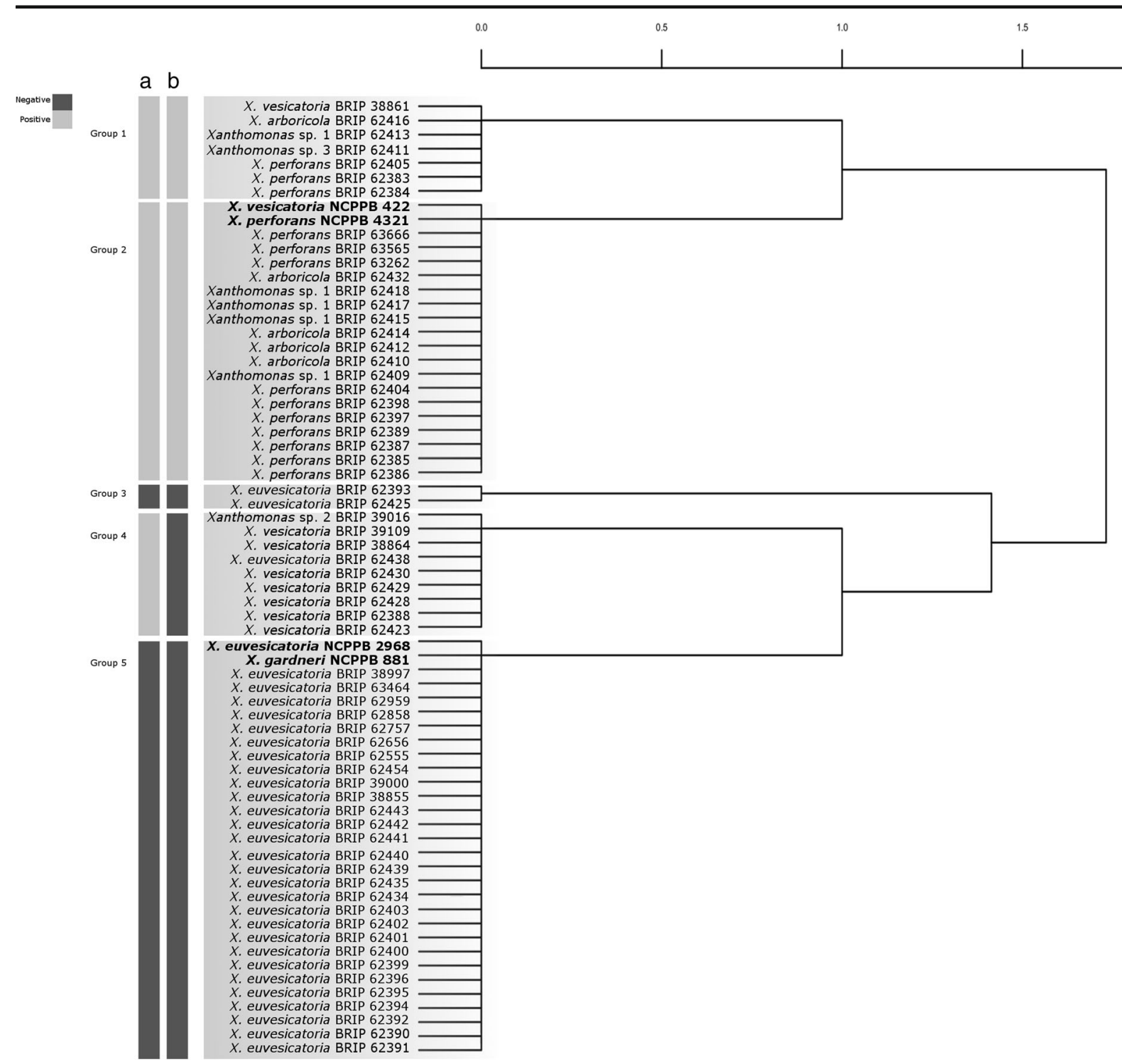

Fig. 2 Hierarchical cluster analysis of biochemical traits from the collected and type isolates. Names are designated as per the clades in Fig. 3. a: starch reaction $\mathbf{b}$ : pectin reaction

every 200 trees. Branch support is reported as posterior probability (PP). A maximum likelihood RaxML (version 7.2.8) tree was also generated for the concatenated gene sequences using a GTR gamma model with 1000 bootstrap replicates (Stamatakis 2014). Images were annotated using FigTree ver. 1.4.2 (Rambaut 2016) and GIMP ver. 2.8.14 (The GIMP team 2014).

The Species Delimitation plugin for Geneious was used to measure relatedness in the generated phylogenies (Masters et al. 2011). Clades and individual sequences were selected to determine which clades were most closely related and supplement the bootstrap values generated in the phylogeny. Single gene and concatenated data sets were checked for recombination in $a t p D$ with RDP (Martin et al. 2015). AtpD sequence was included in this MLSA to better distinguish the $X$. euvesicatoria and $X$. perforans groups.

\section{Results}

Specimen collection

Fifty-seven Xanthomonas-like bacteria isolated from symptomatic tomato, capsicum and chilli crops plants from Qld and NSW from 2012 to 2015 and an additional 


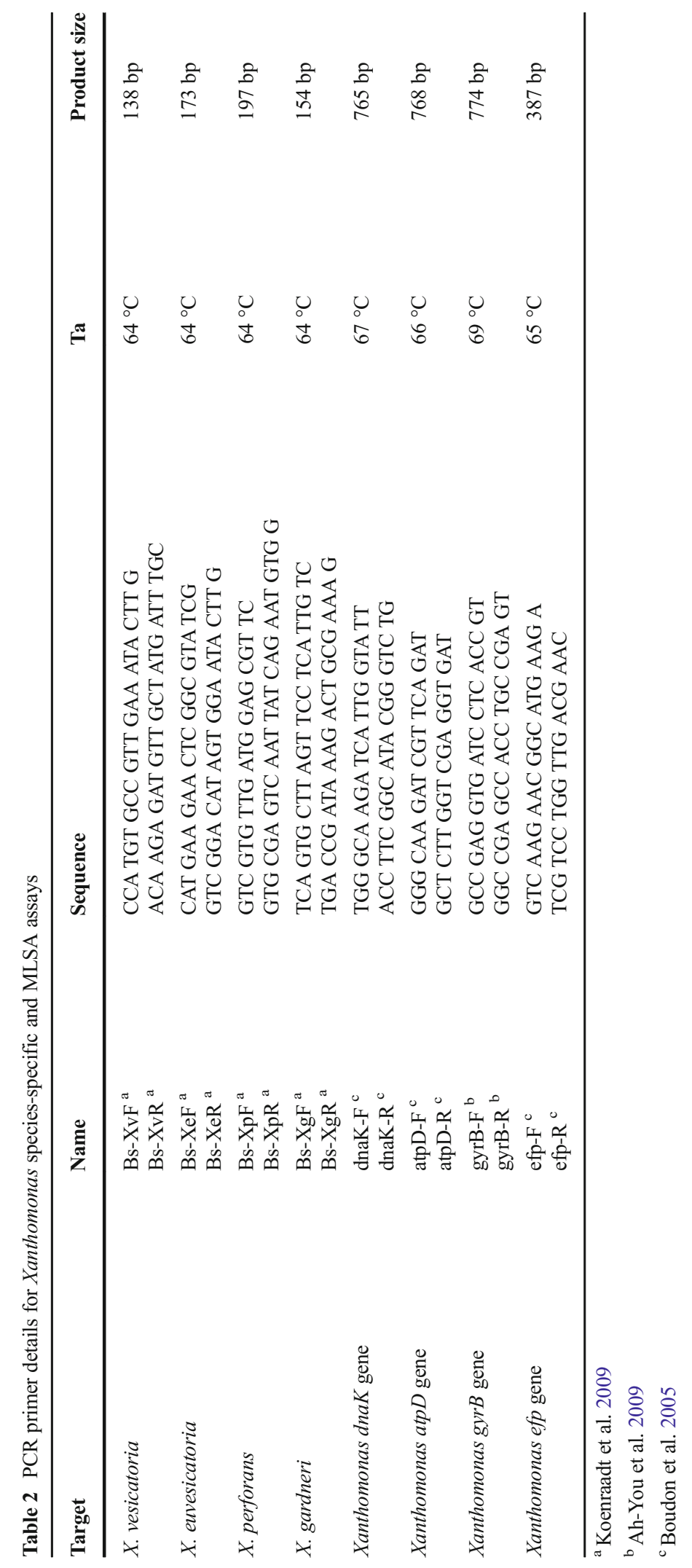


seven isolates from the BRIP collection dating back to 1973, were included in this study (Table 1). Of these 64 isolates, 10 isolates were from capsicum, 21 from chilli, 31 from tomato, and one from each of Nicandra physalodes (apple-of-Peru) and Solanum peruvianum (wild tomato). Additional data from GenBank was included in the MLSA as reference sequence (Table 3 supplementary data).

Biochemical results and pathogenicity

All isolates gave susceptible reactions by infiltration on their host of isolation apart from BRIP 62409, 62411, 62415,62417 and 62418 . These isolates are recorded as non-pathogenic on tomato. Isolates BRIP 62410, 62412, 62414,62416 and 62432 displayed pathogenic reactions when infiltrated but did not display typical lesions when spray inoculated. These isolates are described as weakly pathogenic. All other spray inoculated isolates produced typical BLS symptoms, including isolates from noncrop hosts, BRIP 39016 and 38864.

The biochemical description for members of the Xanthomonas genus is gram-negative, oxidase-negative, catalase positive rods producing yellow colonies on YDC (Schaad 2001). All 68 bacteria (64 Australian and four type isolates) tested $\mathrm{KOH}$ positive (therefore gram-negative), produced yellow colonies on YDC and were negative for the presence of an oxidase enzyme. Sixty-one isolates (including the four type isolates) were strongly or weakly positive for catalase while nine isolates were negative. Variable biochemical test results (starch, pectin and catalase) are described below (Fig. 2).

The biochemical profile of $X$. euvesicatoria (NCPPB 2968) and X. gardneri (NCPPB 881), and 28 Australian isolates from capsicum and chilli were catalase-positive, starch-negative and pectin-negative. The type strains of $X$. perforans (NCPPB 4321) and $X$. vesicatoria (NCPPB 422), together with 18 Australian isolates from tomato were catalase-positive, starch-positive and pectin-positive. The remaining Australian isolates had different biochemical profiles than those of the four type strains. Seven of these isolates from tomato were starch-positive, pectin-positive and catalase-negative. One isolate from $S$. peruvianum, one from $N$. physalodes, one from capsicum and six isolates from tomato (nine total) were catalase-positive, starch-positive and pectin-negative. The remaining two isolates from capsicum were catalase-negative, starch-negative and pectin-negative (Fig. 2).

The cluster analysis of the above biochemical profiles (Fig. 2) identified five groups among the 68 isolates based largely on the variable traits of starch and pectin degradation (Fig. 2). Group 1 of the dendrogram contained 7 isolates, all of which were starch-positive and pectin-positive. Group 2 clustered most closely to group 1 and contained 20 isolates, including the type strains of $X$. vesicatoria and $X$. perforans, which were also starch-positive and pectin-positive. Group 3 contained 2 starch and pectin-negative isolates that were also catalase- negative. Group 4 contained nine starchpositive and pectin-negative isolates. Group 5 contained 30 starch-negative and pectin-negative isolates, including the type strains of $X$. euvesicatoria and $X$. gardneri. Isolates in groups 1, 2 and 4 were from tomato, with the exception that group 4 also contained isolates from $N$. physalodes and S. peruvianum. Groups 2 and 5 contained isolates from capsicum and chilli.

\section{Species specific PCR}

Type strains of $X$. euvesicatoria, X. gardneri, X. perforans and $X$. euvesicatoria were positive for their respective specific PCR tests and negative for the remaining three PCRs (Table 1). Thirty-one isolates, all derived from capsicum and chilli, tested positive for $X$. euvesicatoria. Eight isolates tested positive using the $X$. vesicatoria-specific PCR, seven of which were isolated from tomato and one from $S$. peruvianum. The remaining 25 pathogenic and non-pathogenic isolates (24 from tomato and one from $N$. physalodes) were negative for all 4 species-specific PCR assays. Assays for $X$. euvesicatoria and $X$. vesicatoria generated amplicons, while assays for $X$. perforans and $X$. gardneri did not react with any Australian isolates.

\section{MLSA}

Bayesian inference analysis resolved all 64 Australian isolates collected in this study (Table 1) and additional Genbank sequence (Table 3 supplementary data) in eight strongly supported clades (Fig. 3). Phylogenetic analysis of the dnaK, efp and gyrB genes (Fig. 4 supplementary data) gave the same general topology as the tree including $a t p D$ and grouped isolates in the same clades, as did the RaxML phylogeny (Fig. 5 supplementary data). Each individual gene phylogeny 
Fig. 3 Phylogenetic Bayesian inference tree of concatenated gene sequences (in the order of gyrB, efp, dnaK, atpD) with Genbank reference isolates and posterior probability (percent) branch support values. Type strains are indicated in bold

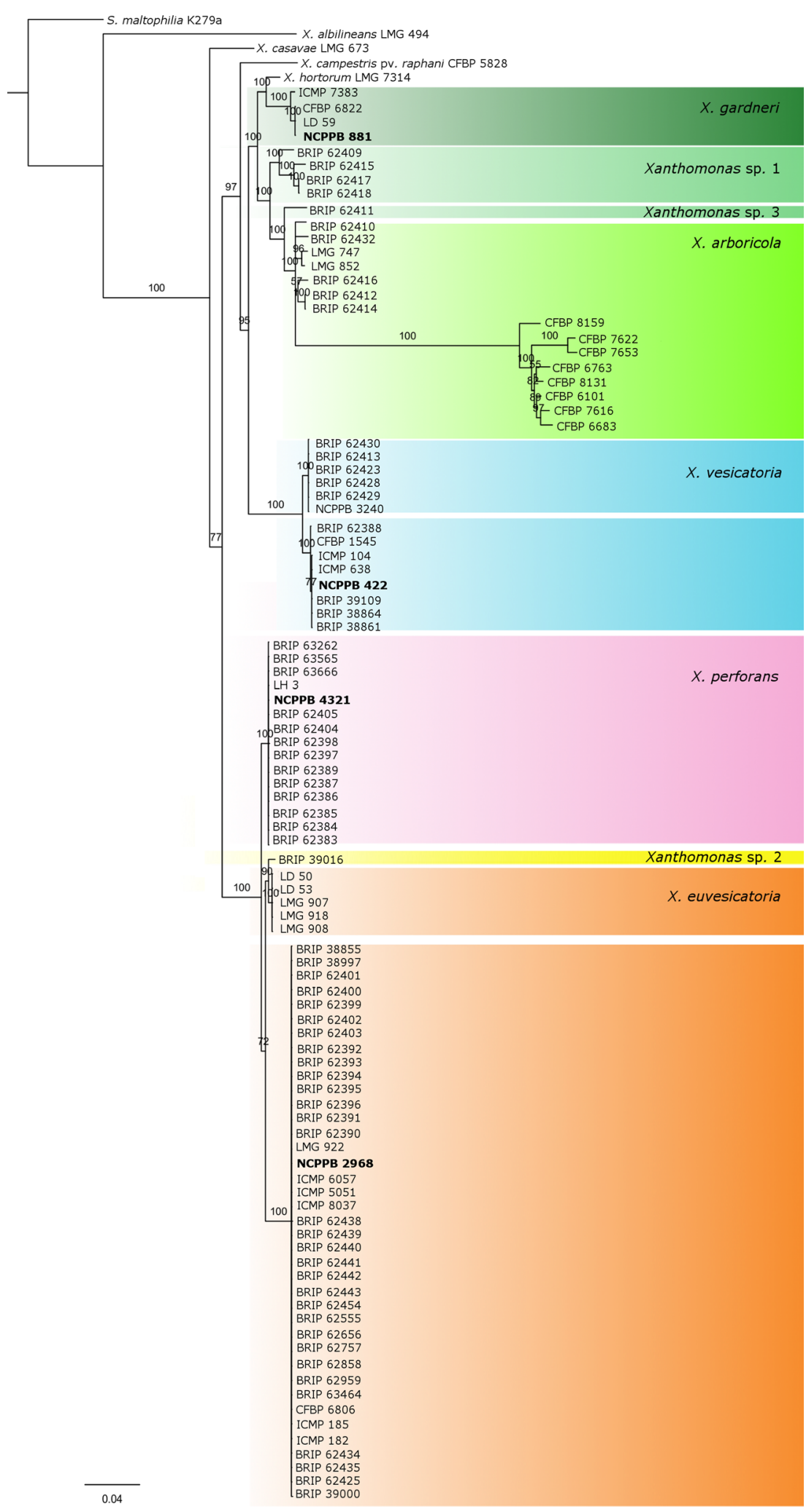


failed to distinguish at least one clade from the other clades. AtpD sequence was included in this MLSA as its absence did not significantly alter the tree topology and its inclusion better differentiated $X$. euvesicatoria and $X$. perforans clades. The recombination events detected in $a t p D$ by Hamza et al. (2012) were not detected by RDP in the single gene or concatenated data sets of these isolates. The species delimitation results supported the relatedness seen in the above phylogenies (supplementary Table 5).

The largest clade (Fig. 3) contained 31 Australian isolates as well as the type strain of $X$. euvesicatoria (NCPPB 2968) from chilli in the USA. This clade also contained seven GenBank reference sequences of $X$. euvesicatoria (supplementary Table 3 ) from capsicum (Brazil, Cook Islands, New Zealand and USA) and chilli (USA). All Australian isolates in this clade were sourced from capsicum and chilli at Bundaberg and Gatton, Qld and Glastonbury and Hawkesbury Heights, NSW. Five $X$. euvesicatoria reference isolates from Hamza et al. (2010) grouped outside the largest $X$. euvesicatoria clade, closest to but separate from the $N$. physalodes (BRIP 39016) isolate. The clade containing the type strain of $X$. perforans (NCPPB 4321) from tomato (USA) also included 13 Australian isolates and a GenBank reference of $X$. perforans (LH 3). These Australian isolates were recovered from tomato at Bowen, Bundaberg and Brisbane (QLD) and South Turramurra (NSW). Two closely related but distinct clades (100\% PP) contained GenBank reference sequence of $X$. vesicatoria and Australian isolates. The first of these clades contained GenBank references of $X$. vesicatoria (NCPPB 3240) from tomato in Spain and five Australian isolates from tomato at Stanthorpe (QLD) and Tenterfield (NSW). The second clade contained the type strain of $X$. vesicatoria (NCPPB 422) from tomato (New Zealand), three GenBank references of $X$. vesicatoria from tomato (France, New Zealand and the USA), three Australian isolates from tomato (Cleveland, Bowen and Victoria Point, QLD) and one from S. peruvianum (Bowen). The clade containing the type strain of $X$. gardneri (NCPPB 881) from tomato (Yugoslavia) also included three GenBank references of $X$. gardneri from Canada, Argentina and New Zealand (supplementary Table 3). None of the Australian isolates were in this clade. A currently uncharacterised clade (Xanthomonas sp.) sister to the $X$. gardneri clade (100\% PP) contained four Australian isolates from tomato in Stanthorpe, QLD.
The type strain of $X$. arboricola (LMG 747) from walnut (New Zealand) was resolved in a clade that contained a Genbank accession of $X$. arboricola pv. pruni from plum (New Zealand), five Australian isolates from tomato (Stanthorpe and Tenterfield, QLD) and a sub-clade (100\% PP) of eight GenBank accessions of $X$. arboricola. One isolate (BRIP 62411, designated Xanthomonas sp. 3) from tomato at Stanthorpe (QLD) was resolved outside the $X$. arboricola clade and the Xanthomonas sp. clade (Fig 3).

\section{Discussion}

Xanthomonas arboricola, X. euvesicatoria, X. perforans, $X$. vesicatoria and at least one undescribed Xanthomonas spp. were identified amongst isolates associated with BLS on capsicum, chilli and tomato crops in eastern Australia on the basis of MLSA, speciesspecific PCR, pathogenicity and biochemical analysis. Of these, only $X$. vesicatoria and $X$. euvesicatoria were previously reported to cause BLS in Australia (EPPO 2013). This study represents the first report of $X$. perforans causing bacterial leaf spot on tomato in Australia. Xanthomonas gardneri was not detected amongst the Australian isolates, and thus may represent a biosecurity threat for Australia. The rapid global spread of $X$. gardneri is highlighted previously (Timilsina et al. 2015), and its absence here further emphasises the importance of seed testing and updated diagnostic protocols as highlighted in other studies (Potnis et al. 2015). The suitability of standard identification techniques and the relationships of Australian Xanthomonas isolates is discussed below.

The methods used to identify the Xanthomonas species associated with BLS in this study highlight a need for updated diagnostic protocols for this disease. The cluster analysis displayed biochemical traits as an unreliable indicator of species and pathogenicity (Fig. 2). The limited reliability of biochemical tests has been observed in other diagnostic and diversity studies, and our results confirm that biochemical data is not sufficient for distinguishing Australian BLS-associated isolates (Berge et al. 2014). Considering further molecular characterisation was necessary, species-specific PCR and MLSA were evaluated. The species-specific PCR assays developed to detect four common Xanthomonas species causing BLS (Jones et al. 2004; Koenraadt et al. 2009) are endorsed as a diagnostic tool by EPPO 
(EPPO 2013). However, these assays provided only partial detection of the Australian BLS-causing species, failing to detect $X$. perforans isolates and one $X$. vesicatoria isolate. The assays were developed with isolates from various geographic regions and subsequently validated with Brazilian isolates, though did not include any Australian isolates (Araujo et al. 2012). MLSA of four genes resolved Australian BLS-causing isolates in species clades consistent with the literature (Hamza et al. 2010) and distinguished them from non-pathogenic strains. The presence of Xanthomonas spp. that were not pathogenic on their host of isolation (Xanthomonas spp., Fig. 3) suggests potential for confounding diagnostics. Based on the findings of this study we suggest that updated diagnostic assays for Australian BLS isolates is needed.

The identification of $X$. perforans from tomato in QLD and NSW represents a new record for Australia. Xanthomonas perforans showed little genetic diversity amongst isolates from Australia and GenBank accessions of $X$. perforans, including the type strain, which is consistent with overseas observations of this species (Timilsina et al. 2015). The biochemical profile for starch and pectin utilisation of the Australian $X$. perforans isolate matched that of the $X$. perforans type strain (NCPPB 4321). Despite this apparent genetic and phenotypic similarity, these isolates did not react with the species-specific PCR that targets $X$. perforans (Koenraadt et al. 2009), possibly due to variation in the primer binding region (eg. indels, mismatch). Additional diagnostic assays will need to be validated for use with Australian BLS-causing $X$. perforans and other Xanthomonas spp. The similarity of $X$. perforans and $X$. euvesicatoria has been noted previously (Timilsina et al. 2015). Merging these species has been proposed, however we refer to $X$. perforans in this study to distinguish this clade from our $X$. euvesicatoria clade. The polyphyletic results of other studies and the highly related sequences of this study indicate whole genome phylogenies with diverse sample groups would further resolve the taxonomy.

Isolates of $X$. vesicatoria from tomato identified in this study separated into two strongly supported subclades that each contained at least one isolate identified as $X$. vesicatoria by Hamza et al. (2012). The $X$. vesicatoria-specific PCR detected the Australian isolates from both subclades. These distinct subclades of $X$. vesicatoria may represent different introductions of the same species from different origins or possibly the existence of two distinct species in Australia. Geographical clade separation of isolates of $X$. vesicatoria from New Zealand and South America has been observed (Timilsina et al. 2015). The biochemical profiles of Australian $X$. vesicatoria isolates differed from the type strain in pectin utilisation, although all were starchpositive. This gives further support to the observation that biochemical traits are not a reliable discriminating test for these species.

Isolates of $X$. euvesicatoria from Australian capsicum and chilli crops were genetically similar to isolates from overseas based on phylogenetic analysis of the $a t p D$, efp, dnaK, and gyrB genes (Ah-You et al. 2009; Hamza et al. 2010, 2012). Australian isolates of $X$. euvesicatoria were positive in the $X$. euvesicatoria species-specific PCR, supporting the grouping of these isolates in the MLSA phylogeny. The $X$. euvesicatoria isolates were generally starch and pectin negative, apart from one isolate (BRIP 62438) that was starch positive. Starch utilisation has historically provided a point of variation for the differentiation of populations of BLS since the early description of $X$. campestris pv. vesicatoria (Doidge 1921; Gardner and Kendrick 1921). Variable starch utilisation has been noted amongst isolates of $X$. euvesicatoria (Bouzar et al. 1996), suggesting some variation in this trait is not unusual and supporting the findings above of unreliable biochemical tests. An isolate from N. physalodes (BRIP 39016; Xanthomonas sp. 2) collected at Christmas Creek (QLD) in 1973 was negative in all of the species-specific PCRs and grouped most closely to the $X$. euvesicatoria clades (Fig. 3) and particularly with reference isolates from Hamza (2010) that formed a small $X$. euvesicatoria clade. Based on these results, it is likely that BRIP 39016 belongs to X. euvesicatoria, though genomic data is need to clarify this.

The inclusion of multiple $X$. arboricola pathovars in the MLSA revealed a highly diverse clade. Five isolates of $X$. arboricola were most closely related to $X$. arboricola pv. pruni and the type strain of $X$. arboricola pv. juglandis by phylogenetic analysis of the $a t p D$, efp, dnaK, and $g y r B$ genes. One isolate, BRIP 62411 , resolved outside of the $X$. arboricola clade in the MLSA analysis and currently remains unclassified (Fig. 3). Xanthomonas arboricola pv. juglandis is starch-positive (Scortichini et al. 2001), as were the five Australian isolates, however Xanthomonas arboricola pv. pruni is recorded as being starch-negative, 
indicating this trait is not uniform among $X$. arboricola (EPPO 2006). The five Australian isolates were also negative in all species-specific PCRs. The MLSA in this study indicates that additional genetic data may provide more accurate resolution of this species. High genetic diversity has been observed in $X$. arboricola previously (Fischer-Le Saux et al. 2015), supporting the levels of diversity reported in this study and indicating further review of the $X$. arboricola species may be necessary. The weakly pathogenic nature of these isolates suggests they may be opportunistic, and $X$. arboricola isolates of uncertain pathogenicity have been previously observed (Fischer-Le Saux et al. 2015). BLS-causing isolates of $X$. arboricola have also been reported in Korea and Tanzania (Myung et al. 2010; Mbega et al. 2012). These were not included in this MLSA due to a lack of sequence data.

Three species are responsible for BLS outbreaks in Australia. Further investigation into the genetics behind the pathogenicity of these species will provide more detailed knowledge of pathogen population dynamics and spread. Instances of race shifts and mutations in populations of Xanthomonas associated with BLS have been recorded overseas (Dahlbeck and Stall 1979; Kousik and Ritchie 1996; Ma et al. 2011), demonstrating that knowledge of population distribution is critical to crop protection. An understanding of the genetic diversity of BLS associated Xanthomonas species in Australia will aid in the development of resistant host lines and diagnostic assays, while also furthering the global understanding of bacterial disease detection and management. Australia's capability for detecting exotic or newly evolved strains will also be improved, especially given the absence of $X$. gardneri, as the observations made in this and subsequent studies will be applicable to exotic Xanthomonas species.

\begin{abstract}
Acknowledgements This work was conducted as part of a $\mathrm{PhD}$ project through La Trobe University with the Queensland Department of Agriculture and Fisheries with funding from the Plant Biosecurity Cooperative Research Centre and Horticulture Innovation Australia.
\end{abstract}

\section{Compliance with ethical standards}

Conflict of interest The authors state they have no conflict of interest
Open Access This article is distributed under the terms of the Creative Commons Attribution 4.0 International License (http:// creativecommons.org/licenses/by/4.0/), which permits unrestricted use, distribution, and reproduction in any medium, provided you give appropriate credit to the original author(s) and the source, provide a link to the Creative Commons license, and indicate if changes were made.

\section{References}

Ah-You, N., Gagnevin, L., Grimont, P. A. D., Brisse, S., Nesme, X., Chiroleu, F., et al. (2009). Polyphasic characterization of xanthomonads pathogenic to members of the Anacardiaceae and their relatedness to species of Xanthomonas. International Journal of Systematic and Evolutionary Microbiology, 59, 306-318.

Anonymous. (1944). Plant diseases. Agricultural Gazette N.S.W, 55(8), 331-335.

Araujo, E. R., Pereira, R. C., Ferreira, M. A. S. V., QuezadoDuval, A. M., \& Cafe-Filho, A. C. (2012). Sensitivity of xanthomonads causing tomato bacterial spot to copper and streptomycin and in vivo infra-specific competitive ability in Xanthomonas perforans resistant and sensitive to copper. Journal of Plant Pathology, 94(1), 79-87.

Benson, D. A., Karsch-Mizrachi, I., Lipman, D. J., Ostell, J., \& Wheeler, D. L. (2005). GenBank. Nucleic Acids Research, 33(Database Issue), D34-D38.

Berge, O., Monteil, C. L., Bartoli, C., Chandeysson, C., Guilbaud, C., Sands, D. C., \& Morris, C. E. (2014). A User's Guide to a Data Base of the Diversity of Pseudomonas syringae and Its Application to Classifying Strains in This Phylogenetic Complex. PloS One, 9(9), e105547.

Boudon, S., Manceau, C., \& Notteghem, J. (2005). Structure and origin of Xanthomonas arboricola pv. pruni populations causing bacterial spot of stone fruit trees in western Europe. Phytopathology, 95(9), 1081-1088.

Bouzar, H., Jones, J. B., Somodi, G. C., Stall, R. E., Daouzli, N., Lambe, R. C., et al. (1996). Diversity of Xanthomonas campestris pv vesicatoria in tomato and pepper fields of Mexico. Canadian Journal of Plant Pathology, 18(1), 75-77.

Constantin, E. C., Cleenwerck, I., Maes, M., Baeyen, S., Van Malderghem, C., De Vos, P., \& Cottyn, B. (2016). Genetic characterization of strains named as Xanthomonas axonopodis pv. dieffenbachiae leads to a taxonomic revision of the X. axonopodis species complex. Plant Pathology, 65(5), 792-806.

Dahlbeck, D., \& Stall, R. E. (1979). Mutations for change of race in cultures of Xanthomonas vesicatoria. Phytopathology, 69(6), 634-636.

Darriba, D., Taboada, G. L., Doallo, R., \& Posada, D. (2012). jModelTest 2: more models, new heuristics and parallel computing. Nat Meth, 9(8), 772-772.

Doidge, E. M. (1920). A tomato canker. Journal of the Department of Agriculture, Union of South Africa, 1, 718721.

Doidge, E. M. (1921). A Tomato Canker. Annals of Applied Biology, 7(4), 407-430. 
EPPO. (2006). Xanthomonas arboricola pv. pruni. EPPO Bulletin, 36(1), 129-133.

EPPO. (2013). PM 7/110 (1) Xanthomonas spp. (Xanthomonas euvesicatoria, Xanthomonas gardneri, Xanthomonas perforans, Xanthomonas vesicatoria) causing bacterial spot of tomato and sweet pepper. EPPO Bulletin, 43(1), 7-20.

Fischer-Le Saux, M., Bonneau, S., Essakhi, S., Manceau, C., \& Jacques, M.-A. (2015). Aggressive emerging pathovars of Xanthomonas arboricola represent widespread epidemic clones that are distinct from poorly pathogenic strains, as revealed by multilocus sequence typing. Applied and Environmental Microbiology., 81(14), 4651-4668.

Gardner, M., \& Kendrick, J. (1921). Bacterial spot of tomato. Journal of Agricultural Research, 21, 123-156.

Griffin, K., Gambley, C., Brown, P., \& Li, Y. (2017). Coppertolerance in Pseudomonas syringae pv. tomato and Xanthomonas spp. and the control of diseases associated with these pathogens in tomato and pepper. A systematic literature review. Crop Protection, 96, 144-150.

Guindon, S., \& Gascuel, O. (2003). A simple, fast, and accurate algorithm to estimate large phylogenies by maximum likelihood. Systematic Biology, 52(5), 696-704.

Hajri, A., Brin, C., Hunault, G., Lardeux, F., Lemaire, C., Manceau, Boureau, T., \& Poussier, S. (2009). A "Repertoire for Repertoire" Hypothesis: Repertoires of Type Three Effectors are Candidate Determinants of Host Specificity Xanthomonas. PloS One, 4(8), e6632.

Hamza, A. A., Robene-Soustrade, I., Jouen, E., Gagnevin, L., Lefeuvre, P., Chiroleu, F., \& Pruvost, O. (2010). Genetic and Pathological Diversity Among Xanthomonas Strains Responsible for Bacterial Spot on Tomato and Pepper in the Southwest Indian Ocean Region. Plant Disease, 94(8), 993-999.

Hamza, A. A., Robene-Soustrade, I., Jouen, E., Lefeuvre, P., Chiroleu, F., Fisher-Le Saux, M., et al. (2012). MultiLocus Sequence Analysis- and Amplified Fragment Length Polymorphism-based characterization of xanthomonads associated with bacterial spot of tomato and pepper and their relatedness to Xanthomonas species. Systematic and Applied Microbiology, 35(3), 183-190.

HIA. (2016). Australian Horticulture Statistics Handbook Vegetables 2014/15. Horticulture Innovation Australia.

Higgins, B. B. (1922). The bacterial spot of Pepper. Phytopathology, 12(11), 501-516.

Huelsenbeck, J. P., \& Ronquist, F. (2001). MRBAYES: Bayesian inference of phylogeny. Bioinformatics, 17, 754-755.

Jones, J. B., Lacy, G. H., Bouzar, H., Stall, R. E., \& Schaad, N. W. (2004). Reclassification of the xanthomonads associated with bacterial spot disease of tomato and pepper. Systematic and Applied Microbiology, 27(6), 755-762.

Jones, J. B., Lacy, G. H., Bouzar, H., Stall, R. E., \& Schaad, N. W. (2006). Reclassification of the xanthomonads associated with bacterial spot disease of tomato and pepper. Systematic and Applied Microbiology, Erratum: Systematic and Applied Microbiology, 29, 85-86.

Jones, J. B., Pohronezny, K. L., Stall, R. E., \& Jones, J. P. (1986). Survival of Xanthomonas campestris pv. vesicatoria in Florida on tomato crop residue, weeds, seeds, and volunteer tomato plants. Phytopathology, 76(4), 430-434.

Jones, J. B., Zitter, T. A., Momol, M. T., \& Miller, S. A. (2014). Compendium of Tomato Diseases and Pests (second ed.). Minnesota: APS Press.
Kearse, M., Moir, R., Wilson, A., Stones-Havas, S., Cheung, M., Sturrock, S., et al. (2012). Geneious Basic: an integrated and extendable desktop software platform for the organization and analysis of sequence data. Bioinformatics, 28(12), $1647-1649$.

Koenraadt, H., van Betteray, B., Germain, R., Hiddink, G., Jones, J. B., Oosterhof, J., et al. (2009). Development of specific primers for the molecular detection of bacterial spot of pepper and tomato. In H. Saygili, F. Sahin, \& Y. Aysan (Eds.), Acta Horticulturae (pp. 99-102).

Kousik, C. S., \& Ritchie, D. F. (1996). Race shift in Xanthomonas campestris pv vesicatoria within a season in field-grown pepper. Phytopathology, 86(9), 952-958.

Larkin, M. A., Blackshields, G., Brown, N. P., Chenna, R., McGettigan, P. A., McWilliam, H., et al. (2007). Clustal W and Clustal X version 2.0. Bioinformatics, 23(21), 29472948.

Ma, X., Ivey, M. L. L., \& Miller, S. A. (2011). First Report of Xanthomonas gardneri Causing Bacterial Spot of Tomato in Ohio and Michigan. Plant Disease, 95(12), 1584-1584.

Madden, T. (2003). The BLAST Sequence Analysis Tool. In J. McEntyre \& J. Ostell (Eds.), The NCBI Handbook. National Centre for Biotechnology Information: Bethesda.

Martin, H. L., Hamilton, V. A., \& Kopittke, R. A. (2004). Copper tolerance in Australian populations of Xanthomonas campestris pv. vesicatoria contributes to poor field control of bacterial spot of pepper. Plant Disease, 88(9), 921-924.

Martin, D. P., Murrell, B., Golden, M., Khoosal, A., \& Muhire, B. (2015). RDP4: Detection and analysis of recombination patterns in virus genomes. Virus Evolution, 1(1), vev003.

Masters, B. C., Fan, V., \& Ross, H. A. (2011). Species Delimitation - a Geneious plugin for the exploration of species boundaries. Molecular Ecology Resources, 11, 154-157.

Mbega, E. R., Mabagala, R. B., Adriko, J., Lund, O. S., Wulff, E. G., \& Mortensen, C. N. (2012). Five Species of Xanthomonads Associated with Bacterial Leaf Spot Symptoms in Tomato from Tanzania. Plant Disease, 96(5), 760-761.

Minsavage, G. V., Dahlbeck, D., Whalen, M. C., Kearney, B., Bonas, U., Staskawicz, B. J., \& Stall, R. E. (1990). Gene-forgene relationships specifying disease resistance in Xanthomonas campestris pv. vesicatoria - pepper interactions. Molecular Plant-Microbe Interactions, 3(1), 41-47.

Myung, I.-S., Jeong, I. H., Moon, S. Y., Lee, S. W., \& Shim, H. S. (2010). A New Disease, Arboricola Leaf Spot of Bell Pepper, Caused by Xanthomonas arboricola. Plant Disease, 94(2), 271.

Ngoc, L. B. T., Verniere, C., Jouen, E., Ah-You, N., Lefeuvre, P., Chiroleu, F., et al. (2010). Amplified fragment length polymorphism and multilocus sequence analysis-based genotypic relatedness among pathogenic variants of Xanthomonas citri pv. citri and Xanthomonas campestris pv. bilvae. International Journal of Systematic and Evolutionary Microbiology, 60(3), 515-525.

Pernezny, K., Roberts, P. D., Murphy, J. F., \& Goldberg, N. P. (Eds.). (2003). Compendium of pepper diseases. Minnesota: The American Phytopathological Society.

Potnis, N., Timilsina, S., Strayer, A., Shantharaj, D., Barak, J. D., Paret, M. L., et al. (2015). Bacterial spot of tomato and pepper: diverse Xanthomonas species with a wide variety 
of virulence factors posing a worldwide challenge. Molecular Plant Pathology., 16(9), 907-920.

Punina, N. V., Ignatov, A. N., Pekhtereva, E. S., Kornev, K. P., Matveeva, E. V., Polityko, V. A., Budenkov, N. I., \& Schaad, N. W. (2009). Occurrence of Xanthomonas campestris pv. raphani on Tomato Plants in the Russian Federation. In H. Saygili, F. Sahin, \& Y. Aysan (Eds.), II International symposium on tomato diseases (Vol. 808, pp. 287-290). Belgium: Int Soc Horticultural Science.

$\mathrm{R}$ core team. (2016). R: A language and environment for statistical computing. Vienna: R Foundation for Statistical Computing http://www.R-project.org/.

Rambaut, A. (2016). FigTree. http://tree.bio.ed.ac. $\mathrm{uk} / \mathrm{software} /$ figtree.

Schaad, N. W. (Ed.). (2001). Laboratory Guide for Identification of Plant Pathogenic Bacteria (3rd ed.). Minnesota: APS Press.

Scortichini, M., Marchesi, U., \& Di Prospero, P. (2001). Genetic Diversity of Xanthomonas arboricola pv. juglandis (synonyms: X. campestris pv. juglandis; $X$. juglandis pv. juglandis) Strains from Different Geographical Areas shown by Repetitive Polymerase Chain Reaction Genomic Fingerprinting. Journal of Phytopathology, 149(6), 325-332.

Shekhawat, P. S., \& Chakravarti, B. P. (1979). Comparison of agar plate and cotyledon methods for the detection of
Xanthomonas vesicatoria in chilli seeds. Phytopathologische Zeitschrift, 94(1), 80-83.

Stamatakis, A. (2014). RAxML Version 8: A tool for Phylogenetic Analysis and Post-Analysis of Large Phylogenies. Bioinformatics, 30(9), 1312-1313.

Sutic, D. (1957). Tomato bacteriosis Bakterioze Crvenog PatlidZana. (Spec. Edit. Inst. Plant Prot., Beograd) Posebna Izd. Inst. Zasht. Bilja, Beograd.

The GIMP team. (2014). GNU Image Manipulation program. www.gimp.org.

Timilsina, S., Jones, J. B., Potnis, N., Goss, E., Minsavage, G. V., Hong, J. C., et al. (2015). Multilocus Sequence Analysis of a Worldwide Collection of Xanthomonas Strains, Causing Bacterial Leaf Spot. Acta Horticulturae, 1069, 27-31.

Vauterin, L., Hoste, B., Kersters, K., \& Swings, J. (1995). Reclassification of Xanthomonas. International Journal of Systematic Bacteriology, 45(3), 472-489.

Vauterin, L., Yang, P., Alvarez, A., Takikawa, Y., Roth, D. A., Vidaver, A. K., Stall, R. E., Kersters, K., \& Swings, J. (1996). Identification of Non-Pathogenic Xanthomonas Strains Associated with Plants. Systematic and Applied Microbiology, 19(1), 96-105.

Young, J. M., Dye, D. W., Bradbury, J. F., Panagopoulos, C. G., \& Robbs, C. F. (1978). A proposed nomenclature and classification for plant pathogenic bacteria. New Zealand Journal of Agricultural Research, 21(1), 153-177. 